Killer Fat 



\section{Killer Fat}

\section{Media, Medicine, and Morals in the American "Obesity Epidemic"}

NATALIE BOERO

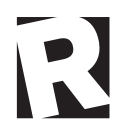

RUTGERS UNIVERSITY PRESS 
Boero, Natalie, I974-

Killer fat : media, medicine, and morals in the American "obesity epidemic" / Natalie Boero.

p. cm.

Includes bibliographical references and index.

ISBN 978-O-8I35-537I-9 (hardcover : alk. paper) - ISBN 978-O-8I35-5372-6 (e-book)

I. Obesity-Social aspects-United States. 2. Obesity-United StatesPsychological aspects. 3. Health in mass media. 4. Body image. I. Title. RC552.O25B64 2012 369.196'398-dc23

2011046939

A British Cataloging-in-Publication record for this book is available from the British Library.

Copyright ( 2012 by Natalie Boero

All rights reserved

No part of this book may be reproduced or utilized in any form or by any means, electronic or mechanical, or by any information storage and retrieval system, without written permission from the publisher. Please contact Rutgers University Press, I06 Somerset Street, New Brunswick, NJ 089o I. The only exception to this prohibition is "fair use" as defined by U.S. copyright law.

Visit our website: http://rutgerspress.rutgers.edu

Manufactured in the United States of America 
For Kristin and Raka 
